\title{
Osobowość typu D i choroba sercowo-naczyniowa: przegląd literatury
}

\section{Personality D type and cardiovascular disease: a literature review}

\author{
EUGENIA MINASIDOU ${ }^{1}$, THEODORA KAFKIA², ALICE DIMITRIADOU ${ }^{3}$, THOMAI \\ KALLIA ${ }^{4}$, MICHAEL KOURAKOS 5
}

${ }^{1}$ RN, MSc, PhD, Assistant professor, Department of Nursing, Alexander Technological Educational Institute of Thessaloniki, Greece

${ }^{2} \mathrm{RN}, \mathrm{MSc}, \mathrm{PhD}$, Clinical Lecturer, Department of Nursing, Alexander Technological Educational Institute of Thessaloniki, Greece

${ }^{3} \mathrm{RN}, \mathrm{PhD}$, Associate professor, Department of Nursing, Alexander Technological Educational Institute of Thessaloniki, Greece

${ }^{4} \mathrm{CM}$, MSc, PhD, Clinical Lecturer, Department of Midwifery, Alexander Technological Educational Institute of Thessaloniki, Greece

${ }^{5}$ RN, MSc, PhD, Director of Nursing Department, General Hospital of AsklepeionVoulas, Athens, Greece

DOI: http://dx.doi.org/10.21784/IwP.2017.012

ISSN: 2451-1846

\section{Streszczenie:}

Na przestrzeni lat naukowcy skupili się na określeniu specyficznych cech osobowości związanych z konkretnymi objawami choroby. Zdrowie psychiczne i stan psychiczny oraz cechy osobowościowe zostały zbadane i zidentyfikowane jako niektóre z czynników prognostycznych choroby sercowo-naczyniowej, jak i fizyczne, takie jak nadciśnienie tętnicze, hiperlipidemia i cukrzyca. W tym artykule skupiono się na charakterystyce osobowości typu D oraz sposobie jego wpływu na początek choroby sercowo-naczyniowej, rokowania i jakość życia pacjentów. Osoby o różnych cechach osobowości różnią się w zależności od choroby. Dokładniej mówiąc, u pacjentów z osobowością typu D stwierdzono, że mają słabe zdrowie ogólne i cierpią z powodu różnych stanów zagrażających życiu. Typowa osobowość typu D i psychiczne cierpienia są ogólnie sugerowane jako przyczyny złego rokowania u chorych na choroby sercowo-naczyniowe, ponieważ pacjenci są mniej przyzwyczajeni do terapii i mają wiele niezdrowych nawyków związanych ze stylem życia, takich jak palenie tytoniu i niskie poziomy aktywności. Wydaje się, że należy zwrócić uwagę na cechy psychiczne i typy osobowości, jako czynniki ryzyka lub czynniki chroniące chorobę układu sercowo-naczyniowego.

Słowa kluczowe: rodzaje osobowości, osobowość D, choroby sercowo-naczyniowe

\section{Abstract:}

Over the years, researchers have focused on identifying specific personality traits associated with specific disease manifestations. Mental health and psychological status, as well as personality characteristics, have been studied and identified as some of the prognostic factors of cardiovascular 
disease, along with physical ones, such as hypertension, hyperlipidemia and diabetes mellitus. This article focuses on Type D personality characteristics and the way it may affect the onset of cardiovascular disease, the prognosis and quality of life of patients. People with different personality characteristics adjust differently to disease. More specifically, people with type D personality have been found to have poor general health and suffer for a variety of healththreatening situations. Type D personality and psychological distress, in general, have been suggested as causes for poor prognosis for patients with cardiovascular disease, as these patients are less adherent to their therapy and have a number of unhealthy lifestyle habits, such as smoking and low activity levels. It seems necessary that attention should be paid to psychological characteristics and personality types, as risk or protective factors for cardiovascular disease.

Keywords: personality types, personality D, cardiovascular disease

\section{Introduction}

Cardiovascular diseases are the major cause of death and disability in the western world as it has been stated by World Health Organization [1]. In 2012, worldwide, the $31 \%$ of deaths were attributed to cardiovascular diseases[1]. The in creasing trend in deaths due to cardiovascular diseases has been attributed to the continuous ageing of the population. By the year 2030 more than 23.600 .000 people are expected to die of coronary disease [1].

Research on cardiovascular disease risk factors is focusing on biologic and lifestyle factors. Hypertension, hyperlipidemia and diabetes mellitus seem to be the main reasons for the onset of cardiovascular disease[2]. Psychologic and social factors, such as social beliefs about health, personal relationships and personality types are stated as important prognostic indicators for health and illness. Moreover, acute and chronic psychological burnout and stress have been incriminated for cardiovascular diseases as well [3].

The role of psychological status and mental health disorders as causative factors, or the ones affecting the onset, development and therapy of cardiovascular diseases, has been proven[4-7].Personality characteristics has been also studied in these surveys. It has been found that there are differences in the way people, with different personalities, perceive and explain disease symptoms and seek for advice from healthcare professionals $[9,10]$.

It is since the early 1970 s that researchers have been focusing on the effect of type A personality on cardiovascular diseases [11]. The oppression, suppression and avoidance of emotion expression have been also found to be connected with cardiovascular diseases $[8,9]$. In the last decades, however, it is becoming more and more common to relate cardiovascular disease to a new type of personality, called personality type D[12-15]. More specifically, poor clinical prognosis, physical and mental status have been associated with type D personality in patients with cardiovascular disease [16]. In addition, other studies have shown that type D personality has been detected in a significant proportion of patients with cardiovascular disease, reaching from $24 \%$ to $37 \%[17,18]$. This is why 
type D personality has been added to the classic risk factors for developing cardiovascular disease [17-19].

The purpose of this literature review is to describe the characteristics of personality type D and their relationship to the manifestation and progression of cardiovascular diseases, aiming at improving the delivery of care of patients.

\section{Review}

\section{Personality types}

For many years, researchers have focused on identifying specific personality traits associated with specific disease manifestations. Major scholars of the psychosomatic school, as it was named, such as Dunbar and Alexander, created the "personality profile" which seemed to be associated with chronic conditions like peptic ulcer or asthma[10].

Five types of personality have been identified based on their main characteristics[personality A, B, C, D and H]. This classification is not referring to pathological personalities. People with type A personality are described as outgoing, ambitious, competitive, aggressive, impatient, hyperactive, workaholics, even during vacation time, with increased sense of control and unrealistic perception of real urgency $[11,13,20]$. Studies have shown that type A personality is associated with hypertension, higher incidences of arrhythmia and major coronary heart diseases [21-24]. Type B individuals are the opposite of type A's. They experience lower stress levels, enjoy achievement regardless of winning or losing, they are more relaxed, creative and reflective. On the other hand, type $\mathrm{C}$ personalities are lonelier, less assertive but with high levels of stress, difficult in expressing emotions, and more vulnerable to depression. This type of personality tends to be controlling for others as well as themselves and has been linked to cancer [25].

Type D personality is similar to type A, with negative feelings and social isolation added to the already mentioned characteristics. Denollet [12] was the first to introduce the term personality D, where D stands for the word Distressed, and it was originally used to study the influence of various personality characteristics on people with coronary artery disease. In the 2000s, the term was used in order to assess bad physical and mental health [26]. Personality D, in clinical psychology, is described as the one characterized by negative emotions such as anxiety, irritability and depression [27]. Individuals with personality D have two main features: negative affectivity and social inhibition. They are experiencing negative emotions and the tendency of not revealing them due to fear of rejection or disapproval from others. People with type D personality are prone to depression and experience difficulties in accepting and utilizing social support and coping [27-30]. Furthermore, they are more likely to smoke more, have higher level of plasma glucose, cholesterol and C-reactive protein [31,32]. 
Finally, people with type $\mathrm{H}$ personality have a deep sense of commitment to their personal values and beliefs; they are in control of their lives, they are challenged by any problem or difficulty and do not give up easily [13,28-30].

\section{Negative emotions}

People with negative emotions have high levels of stress and frustration regardless the period of time or situation in which they are evolved, even if it is not threatening. In general, it is believed that people with negative emotions are mainly focused on the negative side of things [33].They tend to complain quite often and constantly blame themselves and others for everything [10]. Moreover, they experience more intensive feelings of distress, physical symptoms and have low self-esteem. It is not unusual for them to report mild or intense chest pain, with or without actual coronary artery disease.

\section{Social inhibition}

People with social inhibition are characterized by passivity. Their main feature is isolation, shyness and emotional seclusion during social interactions [29]. They refuse to share their feelings and are overwhelmed by fears of disapproval and rejection [10]. They are people superficially calm that avoid interpersonal conflicts. This calmness is interrelated with excessive self-control, which characterize type D personality. In fact, social inhibition reflects the way in which the person faces negative emotions [29].

Social activities for these people are causing insecurity, anxiety and other negative emotions leading to hyper secretion of cortisol in any social activity [34] causing adverse effects on cardiovascular system, such as high blood pressure and/or increased pulse rates and perspiration[35].

The combination of negative emotions and social inhibition may be viewed as a form of stress that can cause or aggravate various health problems $[12,35]$.

\section{Cardiovascular disease and type $D$ personality}

Type D personality was originally defined in order to identify patients with cardiovascular disease who had an increased risk of emotional and personal disorders, such as post-traumatic stress, anxiety, depression and exhaustion. It seems that it is associated with increased morbidity [37], poor quality of life [37], poor prognosis and mortality [38] in patients with cardiovascular diseases [28,39,40]. In addition, people with type D personality have poor general health and a lot of health-threatening situations [41-43]. In general, type D personality ranges from $13 \%$ to $25 \%$ in general population, whereas in patients with cardiovascular disorders it reaches $26 \%$ to $53 \%[29,44,45]$.

Literature data show that type D personality is positively associated with high morbidity and mortality in coronary artery disease patients and negatively with health related quality of life [46]. People with type D personality seem to react differently in any cardiovascular stress. In particular, secretion of cortisol is particularly high in those 
individuals leading to high blood pressure. In addition, increased rate of infections is also quite common. Patients with cardiovascular disease and type D personality are usually neglecting regular blood tests and their medical visits leading to delayed diagnosis and treatment of any medical problems. Type D personality is also associated with lifestyle risk factors, such as smoking, metabolic syndrome and low activity level which can partly explain the relationship with risk of cardiovascular diseases $[16,39,47]$.

Metabolic syndrome and unhealthy lifestyle habits are major risk factors for cardiovascular disease and diabetes mellitus. Metabolic syndrome is a combination of risk factors including central fat deposition, glucose intolerance or insulin resistance, dyslipidemia and hypertension which progressively contribute to atherosclerotic process due to cardiovascular diseases and diabetes. Factors such as smoking, excessive alcohol consumption, unhealthy diet and insufficient physical activity are also associated with cardiovascular disease [48]. Steca et al [11] reported that individuals with metabolic syndrome were at higher cardiovascular risk. Moreover, Svansdottir et al [40] stated that patients with cardiovascular disease and type D personality had high levels of depression and unhealthy habits, such as smoking. In the mid-1990s, Denollet et al[13] reported that not only biological factors play an important role in five-year survival in patients with is chaemic stroke but personality D also. In another study by the same main researcher, it was found that mortality or myocardial infraction in cardiovascular patients with personality D was four times higher [39].

In a study by Pelle et al [49] in patients with coronary heart disease it was found that individuals with type D personality had a lower general health than those with other types of personality. In another study by Yu et al [17] it was demonstrated that patients with type D personality had lower morale and were in more severe condition as compared to those with other personality types. Moryś et al [10] concluded that 52\% of patients with coronary artery disease had also the specific personality type.

In addition, Borsoi et al [50] in a study of patients undergoing dynamic ultrasonography with dobutamine-atropine, have shown that people with type D personality complained more frequently of chest pain than individuals who did not have the previously mentioned personality. Finally, in a study of Mommersteeg et al [51] it was stated that patients with the personality type under study, reported poor health with emotional distress and chest pain. Similar were the results in Greek patients [52]. An increased risk of atrial fibrillation occurrence was reported by Kelpis et al [52]. In conclusion, Williams et al [53] stated that patients with the above described characteristics had low adherence to medication therapy.

\section{Conclusions}

Cardiovascular diseases are one of the leading causes of death and disability in modern western societies. Most studies on risk factors are focusing on biological and lifestyle issues, but acute and chronic psychological stress has been also implicated for the 
pathogenesis of cardiovascular disease, as it was reported by studies on the role of psychologic factors and mental health.

In recent literature, there are references to connection of cardiovascular disease to a new personality type, type $\mathrm{D}$, which characteristics are a tendency to depression and difficulties of acceptance and use of social support. Type D personality is associated with morbidity and mortality in coronary artery disease patients and is adversely affecting their quality of life. Lifestyle, such as smoking, metabolic syndrome, low level of activity and non-adherence to medication are, also, associated to type D personality. Further and more detailed research on the potential connection of cardiovascular manifestations is needed.

\section{Bibliografia/Bibliography:}

1. World Health Organization. [2015]. Cardiovascular diseases[CVDs]. Retrieved from http://www.who.int/mediacentre/factsheets/fs317/en/.

2. Go A.S., Mozaffarian D., Roger V.L., Benjamin E.J., Berry J.D., Blaha M.J., et al. Heart disease and stroke statistics-2014 update: A report from the American heart association. Circulation. 2014;129[3]:e28-292.

3. Lagraauw H, Kuiper J, Bot I. Acute and chronic psychological stress as risk factors for cardiovascular disease: insights gained from epidemiological, clinical and experimental studies. Brain, Behavior and Immunity. 2015;50:18-30.

4. Litchman J., Bigger T., Blumenthal J., Frasure-Smith N., Kaufmann P., Lesperance F., et al. Depression and coronary heart disease: Recommendations for screening, referral and treatment. A science advisory from the American Heart Association Prevention Committee of the Council on Cardiovascular Nursing, Council on Clinical Cardiology, Council on Epidemiology and Prevention, and Interdisciplinary Council on Quality of Care and Outcomes Research: endorsed by the American Psychiatric Association. Circulation. 2008;118[17]:1768-1775.

5. Player M., Peterson L. Anxiety disorders, hypertension and cardiovascular risk: a review. InternationalJournal of Psychiatry in Medicine. 2011;41[4]:365-377.

6. Schwartz B., French W., Mayeda G., Burstein S., Economides C., Bhandari A., et al. Emotional stressors trigger cardiovascular events. International Journal of Clinical Practice. 2012;66[7]:631-639.

7. Tully P., Cosh S., Baune B. A review of the affects of worry and generalized anxiety disorder upon cardiovascular health and coronary heart disease. Psychology, Health \& Medicine. 2013;18[6]:627-644.

8. Kubzansky L.D., Kawachi I. Going to the heart of the matter: do negative emotions cause coronary heart disease? Journal of Psychosomatic Research. 2000;48[4-5]:323-337. 
9. Molloy G., Perkins-Porras L., Strike P., Steptoe A. Type-D personality and cortisol in survivors of acute coronary syndrome. Psychosomatic Medicine. 2008;70[8]:863-868.

10. Moryś J., Bellwon J., Jezewska M., Adamczyk K., Gruchala M. The evaluation of stress coping styles and type D personality in patients with coronary artery disease. KardiologiaPolska. 2015;73[7]:557-566.

11. Steca P., D’Addario M., MagrinM.E., MigliorettiM.,Monzani D., Pancani L., et al.. A Type A and Type D Combined Personality Typology in Essential Hypertension and Acute Coronary Syndrome Patients: Associations with Demographic, Psychological, Clinical, and Lifestyle Indicators. PLoS ONE. 2016;11[9]:1-28.

12. Denollet J., Sys S.U., Brutsaert D.L. Personality and mortality after myocardialinfarction. Psychosomatic Medicine. 1995;57 [6]:582-91.

13. Denollet J., Sys S.U., Stroobant N., Rombouts H., GillebertT.C., Brutsaert D.L. Personality as independent predictor of longterm mortality in patients with coronary heart disease. Lancet. 1996;347[8999]:417-421.

14. Denollet J. Type D personality-A potential risk factor refined. Journal of Psychosomatic Research. 2000;49[4]:255-266.

15. Denollet J., Vaes J., Brutsaert D.L. Inadequate response to treatment in coronary heart disease: Adverse effects of Type-D personality and younger age on 5-year prognosis and quality of life. Circulation. 2000;102[6]:630-635

16. Grande G., Romppel M., Barth J. Association between type D personality and prognosis in patients with cardiovascular diseases: A systematic review and meta-analysis. Annals ofBehavioural Medicine. 2012;43[3]:299-310.

17. Yu X., Zhang J., Liu X. Application of the type D scale [DS14] in Chinese coronary heart disease patients and healthy controls. Journal of Psychosomatic Research. 2008;65[6]:595601.

18. Kupper N., Pedersen S.S., Hofer S., Saner H., Oldridge N., Denollet J. Cross-cultural analysis of type D [distressed] personality in 6222 patients with ischemic heart disease: A study from the international HeartQoL project. International Journal ofCardiology. 2013;166[2]:327-333.

19. Vukovic O., Tosevski D.L., Jasovic-Gasic M., Damjanovic A., Zebic M., Britvic D., et. al. Type D personality in patients with coronary artery disease. PsychiatricaDanubina. 2014;26[1]:46-51.

20. Xu X., Chen Z., Zhang J., Liu X. Coping mediates the association between type D personality and perceived health in Chinese patients with coronary heart disease. International Journal ofBehavioural Medicine. 2011;18[3]:277-284. 
21. Al-Asadi N. Type Abehaviour pattern: is it a risk factor for hypertension? East Mediterranean Health Journal. 2010;16[7]:740-745.

22. Aronowitz R. The Framingham Heart Study and the emergence of the risk factors approach to Coronary Heart Disease, 1947-1970. Revue d'historie des sciences. 2011/2;64[2]:263295.

23. Sharma A. Hypertension: Psychological Fallout of Type A, Stress, Anxiety and Anger. Advances in Asian Social Sciences. 2012;3[4]:751-758.

24. Bokenberger K., Pedersen N., Gatz M., Dahl A. The type A behavior pattern and cardiovascular disease as predictors of dementia. Health Psychology. 2014;33[12]:15931601.

25. Temoshok L., Dreher H. The type C connection: the behavioral links to cancer and your health. Random House, New York. 1992.

26. Aquarius A.E., Denollet J., Hamming J.F., De Vries J. Role of disease status and Type D personality in outcomes in patients with peripheral arterial disease. American Journal of Cardiology. 2005;96[7]:996-1001.

27. Du J., Zhang D., Yin Y., Zhang X., Li J., Liu D., et al. The personality and psychological stress predict major adverse cardiovascular events in patients with Coronary Heart Disease after percutaneous coronary intervention for five years. Medicine [Baltimore]. 2016;95[15]:e3364-3370.

28. Denollet J., Brutsaert D.L. Personality, disease severity, and the risk of long-term cardiac events in patients with a decreased ejection fraction after myocardial infarction. Circulation. 1998;97[2]:167-73.

29. Denollet J. DS14: standard assessment of negative affectivity, social inhibition, andType D personality. Psychosomatic Medicine. 2005;67[1]:89-97.

30. Denollet J., Kupper N. Stress and the heart: the role of type D personality in personalized care. European Heart Journal. 2015;36[28]:1783-1785.

31. Van Gestel Y., Pedersen S., van de Sande M., de jaegere P., Serruys P., Erdman R., et al. TypeD personality and depressive symptoms predict anxiety 12 months post-percutaneous coronary intervention. Journal of Affective Disorders. 2007;103[1-3]:197-203.

32. Whitehead D.L., Perkins-Porras L., Strike P.C., Magid K., Steptoe A. Cortisol awakening response is elevated in acute coronary syndrome patients with type-D personality. Journal of Psychosomatic Research. 2007;62[4]:419-425.

33. Sher L. Type-D personality: the heart, stress, and cortisol. QJM. 2005;98[5]:323-329. 
34. Watson D., Pennebaker J. Health complaints, stress, and distress: exploring the central role of negative affectivity. PsychologyReviwe. 1989;90[2]:234-254.

35. Rosmond R., Bjorntorp P. The hypothalamic-pituitary-adrenal axis activity as a predictor of cardiovascular disease, type 2 diabetes and stroke. Journal of InternalMedicine. 2000;247[2]:188-197.

36. Kupper N., Denollet J. Type D personality as a prognostic factor in heart disease: Assessment and mediating mechanisms. Journal of Personallity Assessment. 2007;89[3]:265-76.

37. Van den Broek K.C., Nyklicek I., van der Voort P.H., Alings M., Meijer A., Denollet J. Risk of ventricular arrhythmia after implantable defibrillator treatment in anxious type D patients. Journal of American College of Cardiology. 2009;54[6]:531-537.

38. Pedersen S.S., Denollet J. Type D personality, cardiac events, and impaired quality of life: a review. European Journal of Cardiovascular Prevention \&Rehabilitation. 2003;10[4]:241248.

39. Denollet J., Pedersen S.S., Vrints C.J., Conraads V.M. Usefulness of type D personality in predicting 5-year cardiac events above and beyond concurrent symptoms of stress in patients with coronary heart disease. American Journal of Cardiology. 2006;97 [7]:970973.

40. Svansdottir E., van den Broek K.C., Karlsson H.D., Gudnason T., Denollet J. Type D personality is associated with impaired psychological status and unhealthy lifestyle in Icelandic cardiac patients: A cross-sectional study. BMC Public Health. 2012;12:42-52.

41. Mols F., Oerlemans S., Denollet J., Roukema J., van de Poll-Franse L. Type D personality is associated with increased comorbidity burden and health care utilization among 3080 cancer survivors. General Hospital Psychiatry 2012;34[4]:352-359.

42. Schoormans D., Mulder B., van Melle J., Pieper E., van Dijk A., Sieswerda G. et al. Patients with a congenital heart defect and type D personality feel functionality more impaired, report a poorer health status and quality of life, but use less healthcare. European Journal of Cardiovascular Nursing 2012;11[3]:349-355.

43. Starrenburg A., Kraaier K., Pedersen S., van Hout M., Scholten M., van der Palen J. Association of psychiatric history and type D personality with symptoms of anxiety, depression, and health status prior to ICD implantation. International Journal ofBehavioural Medicine 2013;20[3]:425-433.

44. Pedersen S.S., Denollet J. Validity of the Type D personality construct in Danish postMI patients and healthy controls. Journal of Psychosomatic Research. 2004;57[3]:265-272.

45. Conraads V.M., Denollet J., De Clerck L.S., Stevens W.J., Bridts C., Vrints C.J. Type D personality is associated with increased levels of tumour necrosis factor [TNF]-alpha and 
TNF-alpha receptors in chronic heart failure. International Journal of Cardiology. 2006;113[1]:34-8.

46. O’Dell K., Masters K., Spielmans G., Maisto S. Does type-D personality predict outcomes among patients with cardiovascular disease? A meta-analytic review. Journal of Psychosomatic Research. 2011;71[4]:199-206.

47. Mommersteeg P.M., Pouwer F. Personality as a risk factor for the metabolic syndrome: A systematic review. Journal of Psychosomatic Research. 2012;73[5]:326-333.

48. Mommersteeg P., Kupper N., Denollet J. Type D personality is associated with increased metabolic syndrome prevalence and an unhealthy lifestyle in a cross-sectional Dutch community sample. BMC Public Health. 2010;10:714-725.

49. Pelle A., Erdman R., Van Domburg R., Spiering M., Kazemier M., Pedersen S. Type D patients report poorer health status prior to and after cardiac rehabilitation compared to non-type D patients. Annals ofBehavioural Medicine 2008;36[2]:167-175.

50. Borsoi R., Sabatoski V.V., Ogawa A.P.H., Fontana A., Baroncini L.A.V., de Souza A.M., et al. Occurrence of Myocardial Ischemia in Patients Undergoing Pharmacologic Stress Echocardiography: The Impact of Type-D Personality. International Journal of Preventive Medicine. 2014;5[7]:895-899.

51. Mommersteeg P.M., Pot I., Aarnoudse W., Denollet J., Widdershoven J.W. Type D personality and patient-perceived health in nonsignificant coronary artery disease: the TWeestedenmIldSTenosis[TWIST] study. Quality of Life Research. 2013;22[8]:2041-2050.

52. Kelpis T.G., Anastasiadis K., Nimatoudis I., Kelpi M.G., Hadjimiltiades S., Papakonstantinou C. Prevalence of "Distressed" Personality in Patients with Coronary Artery Disease and Its Correlation with Morbidity After Coronary Surgery. Hellenic Journal of Cardiology. 2013;54[5]:362-367.

53. Williams L., O'Connor R.C., Grubb N.R., O'Carroll R.E. Type D personality and illness perceptions in post-myocardial infarction patients. Journal of Psychosomatic Research. 2011;70[2]:141-144. 